\title{
Climate Change Adaptations for Coastal Farms: Bridging Science and Mātauranga Māori with Art and Design
}

\author{
Martin Bryant, Penny Allan, Huhana Smith
}

\begin{abstract}
Indigenous coastal farming communities need to address future climate change impacts, yet many communities are slow to respond, due to lack of adequate information, economic pressures, the abstract nature of climate change science and poor communication between what science knows and what indigenous farming communities need to know. Art and design can address these issues by synthesizing broad scientific principles with local place-specific culture and their visual language can effectively communicate short and long-term benefits to local communities. Art and design are thus both generative research methods and media for representation. This research uses art and design to provide a bridge between the Māori culture of a local farming community in coastal New Zealand and climate change science. It provides a framework of strategies for new farm practices. Underpinned by the qualitative awareness of thresholds and an open-ended toolbox of land-based strategies, the role of the framework is to catalyze adaptation. The framework is responsive to both the Māori worldview and scientific knowledge, and has the potential to provide a model for other coastal communities.
\end{abstract}

Keywords: climate change, coastal communities, coastal farming, exhibitions, indigenous methods

This essay discusses the outcomes of a research project, "Adaptation Strategies to Address Climate Change Impacts on Coastal Māori Communities," which was funded by the New Zealand Government's Vision mātauranga (knowledge) strand of the Te Kōmata o Te Tonga (Deep 
South) National Science Challenge, and undertaken with Māori coastal communities in the Horowhenua - Kāpiti rohe (region). The research team included experienced kaupapa Māori researchers, landscape architects, architects, climate change scientists, and ecological economists. ${ }^{1}$

The research builds on a research partnership established to investigate the potential of working between cultures and with different worldviews to solve site specific, environmental problems in culturally appropriate ways. At the heart of this partnership was a protocol designed to provide a third space at the interface between cultures, affording each system its own integrity while encouraging approaches that might incorporate aspects of both. ${ }^{2}$ The protocol has informed all subsequent research, which has continued to explore the implications of the protocol for art and design. The current research project focuses on two parallel but interdependent research activities. One was intent on drawing links between mātauranga Māori and the science of climate change; and the other was an applied design research that identified options for adaptation to climate change for coastal Māori communities and their farming practices. Both looked at the potential for culturally specific methodologies and values to create a framework for collaboration: developing a set of culturally aligned research practices, bridging the gap between worldviews and facilitating productive research with local Māori communities. Both used art and design to challenge thinking and to generate and communicate solutions. Our research posed the following question: how might art and design productively bridge the gap between science and mātauranga Māori, and catalyze a coastal farming community to adapt to climate change?

\section{THE PROBLEM: THE THREAT OF SEA LEVEL RISE TO MĀORI COASTAL FARMS}

Many coastal Māori farming lands located on lowlands beside the New Zealand coast are at risk from climate change. The Horowhenua region north of Wellington is a prime example (Fig. 1). Māori hapū (family shareholders), continue to work tracts of ancestral coastal farming land in Horowhenua between the Ōhau and Waikawa Rivers in the south-western coastal region of Te Ika ā Maui (North Island). In the past, diverse resource gathering activities such as tuna (eel) fishing, inanga (whitebait), harakeke (New Zealand flax), harvesting for production of muka (silk-like thread) and horticultural activities such as vegetable growing were commonplace here. Now, dairy farming is the most profitable and most prolific land use. However, at some point in the next century, because of climate change, most of this land is likely to be permanently inundated (Fig. 2). ${ }^{3}$ Not surprisingly, compelling solutions are complex. Climate change science, geomorphological, archaeoseismological, hydro-ecological and ecological research can provide quantifiable and factual data as a valuable guide. But the uncertainty of climate change predictions and the complexity of climate change science make farmers reluctant to prepare for and work toward long-term solutions. The challenge is less about providing certainty, 


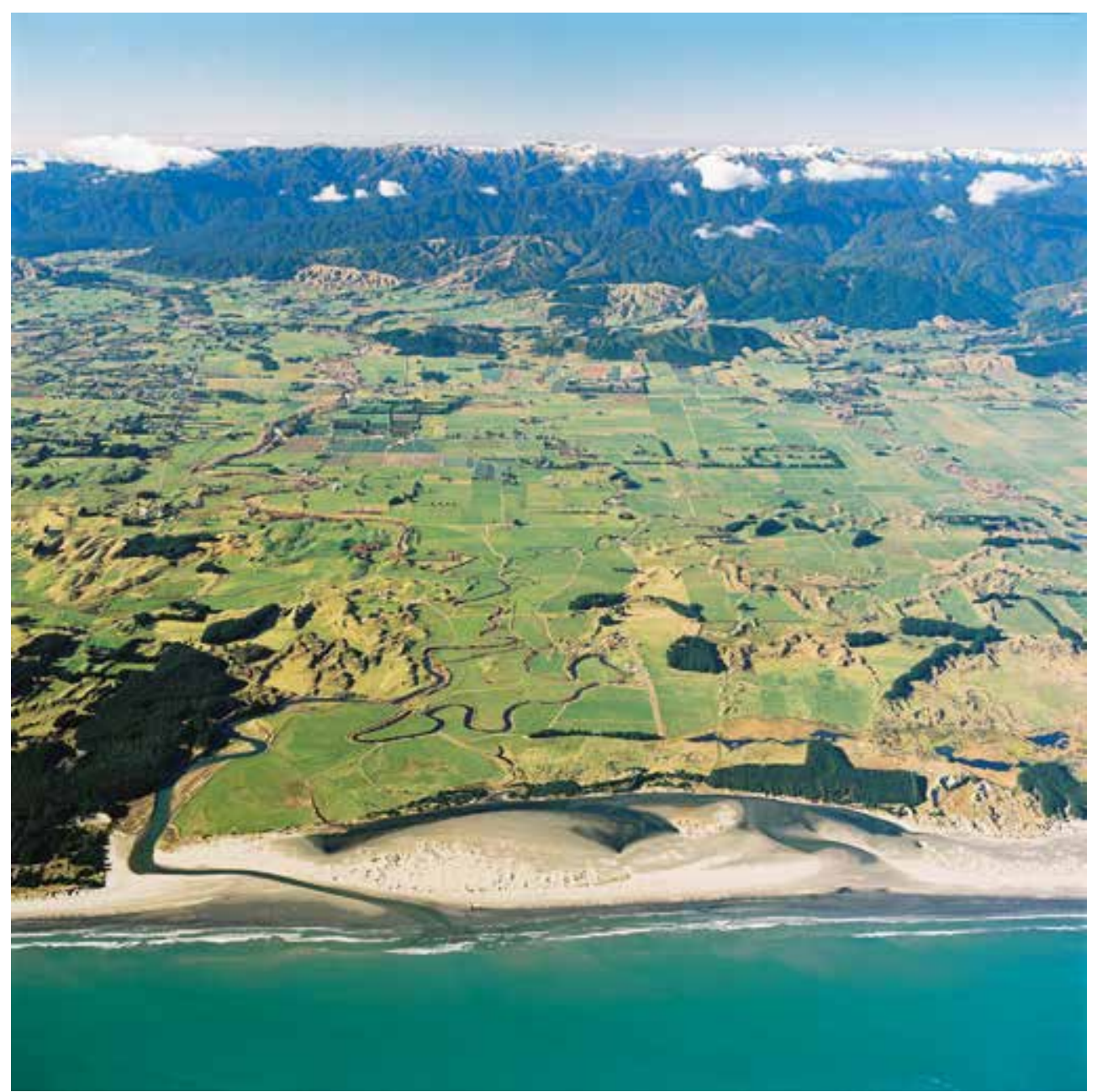

Figure 1. Birds' eye view of the farm showing the Ōhau River, parabolic dune landscape and Tararua Ranges in background.

and more about finding ways to persuade economically-conservative and culturally-aware Māori farmers and their whanau (family) of the exigencies associated with climate change and the opportunities that adaptation might offer for short-term and long-term well-being, cultural health and economic viability.

\section{THE CASE STUDY: THE TAHAMATA INCORPORATION FARM}

This research project looks specifically at the Tahamata Incorporation farm, ${ }^{4}$ a five hundred ha [1235.5 acres] tract in the Howowhenua rohe which lies between the waterways of the Kuku Stream, the banks of the Ōhau River at Te Rauawa, and the Kuku Ōhau estuary.

The farm is part of a long coastal plain fed by multiple rivers from the Tararua Ranges, that once supported one of New Zealand's most significant stretches of wetlands. When rivers meet the sea, contrary forces confront each other, both above and below ground. The tidal seas force the rivers 

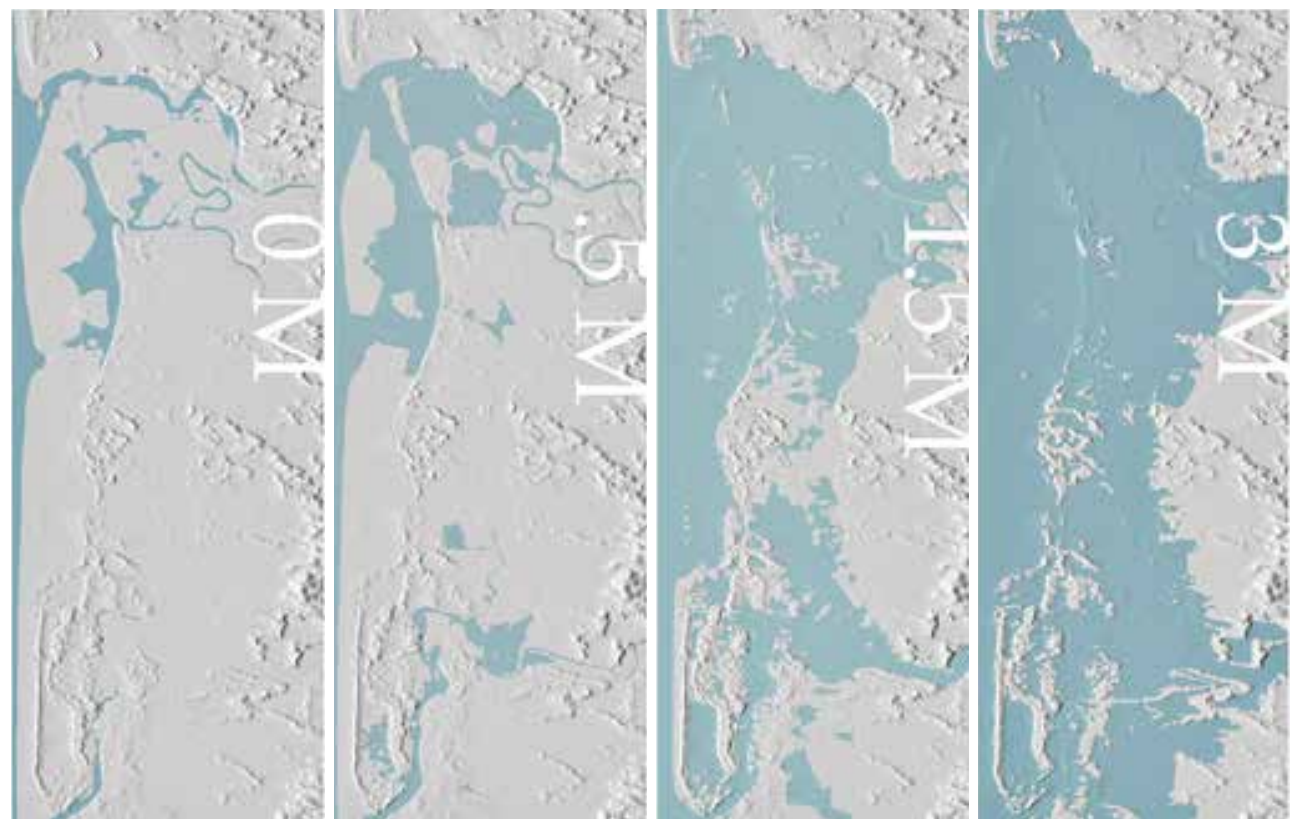

Figure 2. Drawings indicating impacts of sea level rise on the farm over time.

to spread across the land, to change their courses, or to push water up from the ground to the surface. In the past, these rivers regularly spread rich alluvial soils across the plain and charged extensive wetlands and aquifers, creating an abundant and biodiverse environment for Māori who have lived here for centuries. Today, there is still strong Māori presence on the farmlands, in the marae-centered community settlements and at iwi-run kura or wānanga (Māori schools and university).

Farming has been highly productive because of the rich soils and plentiful water. But increased settlement and productivity-driven dairy farming in the last fifty years have had significant environmental, social and cultural impacts. Rivers have been channelized, wetlands reclaimed, and the remnant natural ecosystems now lack connectivity and biodiversity. And yet, the low-lying land is still wet, so famers revert to "proven" practices like draining the most arable land, while dairy cattle continue to destroy the fragile soil structure and pollute waterways and the demand for higher yields on less land has resulted in elevated concentrations of nutrients in the water systems. ${ }^{5}$ Unfortunately, the financial difficulties associated with farming marginal land encourages resistance to change and a perpetuation of the status quo.

Iwi (tribes) and hāpu are concerned with the resulting disassociation between land and culture. The farming activities deplete mauri (vital essence) and devalue ecosystem services and the broad acre practices make farms inaccessible on a day-to-day basis for many of the shareholders, resulting in the diminishing of resource gathering traditions. Only interested ahi kā (those who live in the region) can uphold and maintain land-based customs and values. ${ }^{6}$ 
Because of the shallow gradient of the coastal plain, sea level rise over the next hundred years is likely to dramatically decrease the area of arable land on the farm, increase ground water salinity, erode the coastal dunes, increase the frequency and severity of flood events and threaten the habitat of the remnant wetlands behind the dunes. ${ }^{7}$ Current farming practices will exacerbate these impacts because rather than recognizing the inherent benefits of wetlands and dunes as climate change buffers, farmers tend see them as antithetical to efficient farm management and actively seek their removal.

\section{NEW METHODS FOR CREATING RELATIONSHIPS BETWEEN SETTLEMENT, FARMING AND ECOLOGY}

Some macro-economists argue that globalization with its economies of scale opens up possibilities to solve large environmental problems (like climate change) with macro-economic legislation, top down policy-based solutions (like carbon taxes) or large scaled infrastructural solutions (like building higher levee banks to minimize flooding impacts). ${ }^{8}$ This protectionist, defensive and mechanistic model perpetuates the primacy of economics in decision-making and, for farming, justifies an approach that reinforces the demand for maximizing yield. What is often missing in this equation is, firstly, the importance of communicating the urgency of climate change science to these communities and, secondly, the potential of communities and place to play a role in site specific and culturally appropriate adaptations to climate change.

This research project was as much about a search for new culturally appropriate methods to challenge thinking and help communicate the urgency of climate change as it was about finding solutions. To develop new methods, we investigated customary Māori knowledge and western scientific knowledge concurrently and used iterative art and design methods as a bridge between them. For example, we looked at the critical relationships between atmosphere, land, water and people identified by mātauranga Māori and western science and interpreted these through mappings and exhibitions to shed light on each knowledge system. We used the alignment in both worldviews regarding indicators, thresholds and human agency to experiment with visual techniques for communicating the urgency of climate change more effectively. We synthesized, through design, the complexity of global and local influences in order to address local land and culture-based issues at a human scale. We developed a suite of adaptive solutions that could empower the local community to adapt in their own way and their own time. And we communicated, through hui (meetings), wānanga (workshops) and exhibitions, the potential for Māori farming communities, in the short and long term, to regenerate a culturally, environmentally and economically prosperous future.

Each step in developing art and design was thus framed by mātauranga Māori values, and underpinned by scientific knowledge. Together, these methods allowed us to create new, culturally appropriate place-based 
relationships between settlement form, culture, farming and an enhanced ecological environment. Some of these processes are described in more detail below.

\section{MĀTAURANGA MĀORI}

Mātauranga Māori is a contemporary Māori term for an indigenous worldview that has changed, adapted and been developed, due to impacts of colonization over generations. Mātauranga Māori not only draws on key themes and ideas from a traditional knowledge base, but also acknowledges that the changes inform new paradigms. The research team are well aware that there is a crucial need to re-engender the role of human interdependencies and inter-relationships to each other, to the natural, spiritual and cultural in landscape, and to allow dynamic movement between them. This thinking is central to a Māori environmental worldview, founded on a spiritual dimension to land, waterways and being, and operating in a way that transcends analytical science. For example, kaumātua (elders) of Ngāti Tūkorehe and Ngāti Wehiwehi have often spoken of narratives of occupation and settlement on these lands, of inter-tribal contest that customarily changed land tenure, of the cultural importance for sacred and natural areas within the inland coastal waterways and of the many coastal areas that were restricted from human access and activity. Such kaumātua accounts recall long observed and consistent protocols that relate to land and waterways, which draw upon a mātauranga Māori knowledge base.

The research investigated the potential of three mātauranga Māori knowledge-creation methods for this project that embrace the ideas of the interconnectedness of all knowledge and the way knowledge is collected and dispersed. Whakapapa describes the interconnection between all things, Hīkoi is about observing knowledge, sensing it and feeling it especially through a journey across lands and along waterways and kōrero tuku iho (oral traditions) provides the language and moments that connect things and place, with the nature of being. In order to address more fully the interconnection processes of these methods, we focus on two - whakapapa and kōrero tuku iho - in more depth in the following section.

\section{Whakapapa}

Iwi and hāpu in this coastal region historically negotiated a diverse range of meanings between customary and contemporary Māori environmental world-views and aspirations for change. ${ }^{9}$ Whakapapa is the definitive genealogical reference system for hapū and whanau, where the adept recite their connections to each other, to their lands, waterways, ecosystems and areas of spiritual importance. To this day, particular kaumātua and knowledge holders in the region have a mandate to retain a high level of whakapapa understanding, and disseminate it accurately and accordingly from the paepae (main speakers' row of seating) at local 
marae, across marae (meeting grounds) of the region and the country. As a fundamental aspect of Māori customs, values and attitudes, whakapapa encapsulates potential, creativity and the promise of wellbeing to come. It is a way of looking at whenua or land as interconnected and interdependent layers of histories, interactions or activities. While the cycles of change occur over time, memories remain embodied in lands and waterways through these many historical and cultural layers. The forces of whakapapa are also embedded in the cycles of moons and tides that make change every day, whereby we adapt to these cycles for our food and sustenance, water and well-being.

\section{Kōrero Tuku Iho}

Körero tuku iho (oral narratives) are ways of telling narratives of the past, the present and the future orally within a mātauranga Māori way of knowing. These narratives build upon whakapapa understandings, which establish the spiritual and physical association between lands, waterways and people. Oral narratives expand on the sequences of the hìkoi, and illuminate moments experienced during journeys through whenua. And they can highlight key moments where practices changed. For example, when a catch of tuna was landed in a full tide after a dry season, a new practice for fishing was instigated, or when a harvest was ruined by flood and hapū needed to move cultivations to higher ground. These moments are thresholds: when people go through an uncertain period and then adapt to a new way of living.

\section{BRIDGING MĀTAURANGA MĀORI AND SCIENCE}

\section{Mapping Cycles}

Scientific data on climate change is often presented in graphs over known time periods to show trends that can be projected into the future. For example, recent climate change graphs in IPCC reports show an alarming projected rise of temperatures in the next 100 years. ${ }^{10}$ Typically, climate change graphs are shown as representations of linear time, with a gradual increase over the last two hundred years followed by a steep gradient projecting towards a future that is all the more frightening because it is unpredictable.

We interpreted the scientific data on global sea levels through a process of mapping, to describe the cyclic interdependencies between water and atmospherics over hundreds and thousands of years. We showed the cycles of sea level in flux over 400,000,10,000 and the last thirty years, and overlaid these with the influence of EI Niño and La Niña, the annual cycle of the tides caused by the earth's orbit around the sun, the monthly influence on the tides when the moon and sun are aligned, and finally the diurnal cycle caused by the gravitational pull of the moon as the earth spins on its axis. In representing the map as a field of influences, we were 
recognizing the current change in climate as part of a much bigger, more complex and interdependent system of atmosphere, land and water. In our first exhibition, we positioned the graph cycles on glass in front of a powerful image that portrays the stillness and shifting qualities of the mouth of the Ōhau River. In this exhibition, we were attempting to highlight the interdependence of qualitative and quantitative methods - what looks still is nevertheless in flux and abstract representations have a qualitative dimension - and that western science tends to rely on one over the other (Fig. 3).

\section{Finding Indicators}

The maramataka, or Māori lunar calendar (Fig. 4), was mapped from data found in New Zealand's national archives. Its embedded knowledge is based on direct experience, transmitted through körero tuku iho, remains relevant to today's descendants of the Metera Te Ao Marere of Ōtaki, who was the originator of this version of maramataka. It charts the relationship between the rhythms of the land and sea, climatic events such as storm surges governed by the moon and cycles of the tides and associated daily rituals relating to the gathering and management of resources.

Like the graph cycles in the first exhibition, the maramataka is based on interdependencies between water and atmospherics, but it is also specifically about culture and agency. It records cyclical change, and the opportunities that result from that change, clearly setting out what one can do in response to very specific environmental indicators. For example, each night of a lunar month was named and described according to how favorable or unfavorable it was for fishing, eeling or planting.

The difference between the mappings also reflects Fikret Berkes' view of the difference between scientific and indigenous knowledge systems: the first about content, the second, process. It reinforces the importance in any site-specific climate change solution of a knowledge system drawn from the land. As Berkes suggests, indigenous farming community can

Actively build a knowledge base of climate change because they use the land and resources, and (have developed) the sensitivity to "read" critical signs and signals from the environment that something unusual is happening. If they were not constantly interacting with the land, they would not be able to respond effectively to what they were observing. ${ }^{11}$

\section{Thresholds}

While we were designing the maramataka, we were also working with the science team to understand the long-term climate change impacts for the farm. Recent research in Hawai'i reveals that all low-lying coastal plains in the South Pacific are at risk of inundation, not just from the sea, but from a combination of sea level rise and groundwater, ${ }^{12}$ and that the pace of 

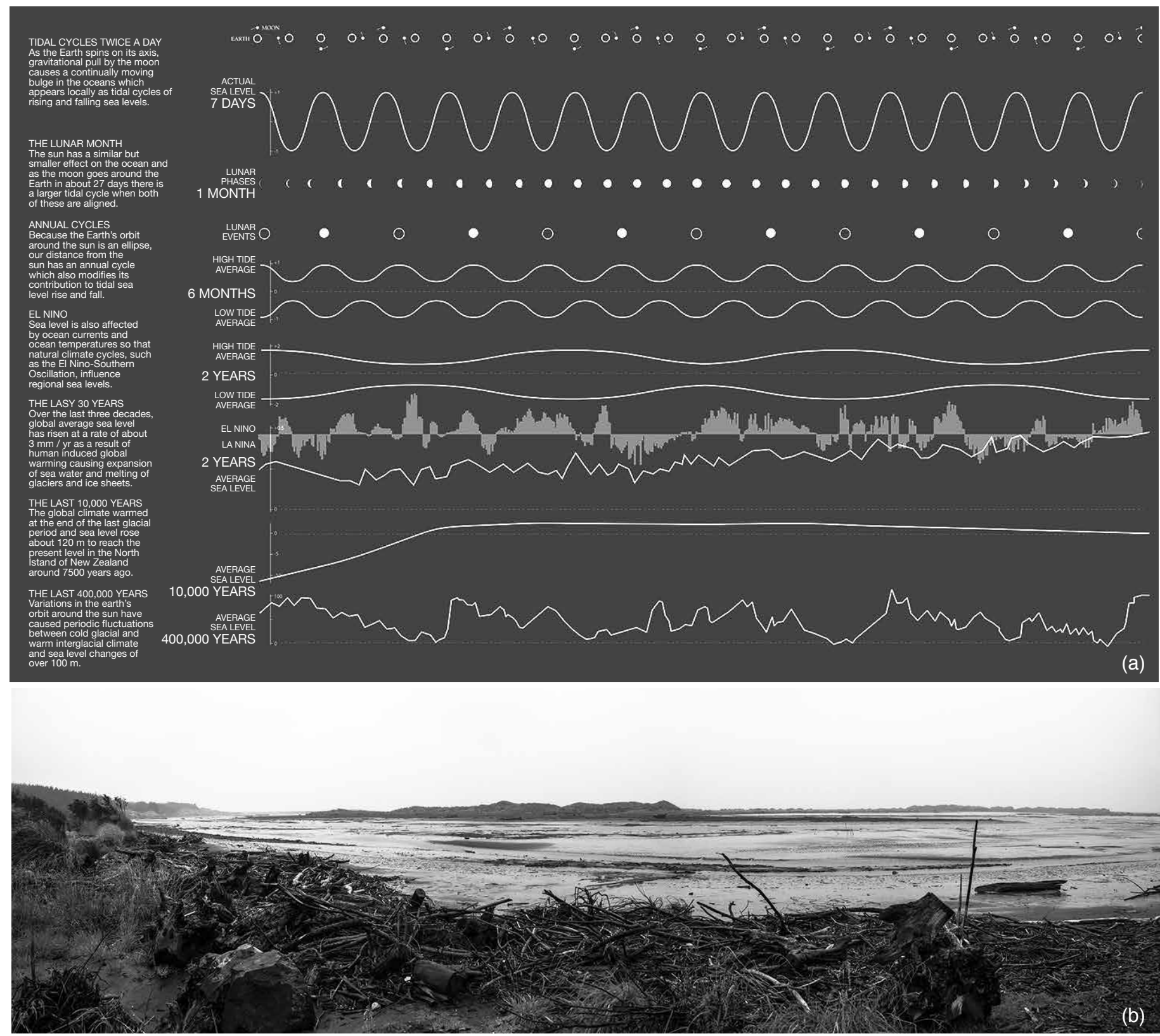

Figure 3. Cycles of weather and water (a); Ōhau river mouth (b); first exhibition at the School of Architecture, Victoria University of Wellington, showing graph cycles on window and image of river mouth by Martin Manning behind (c).

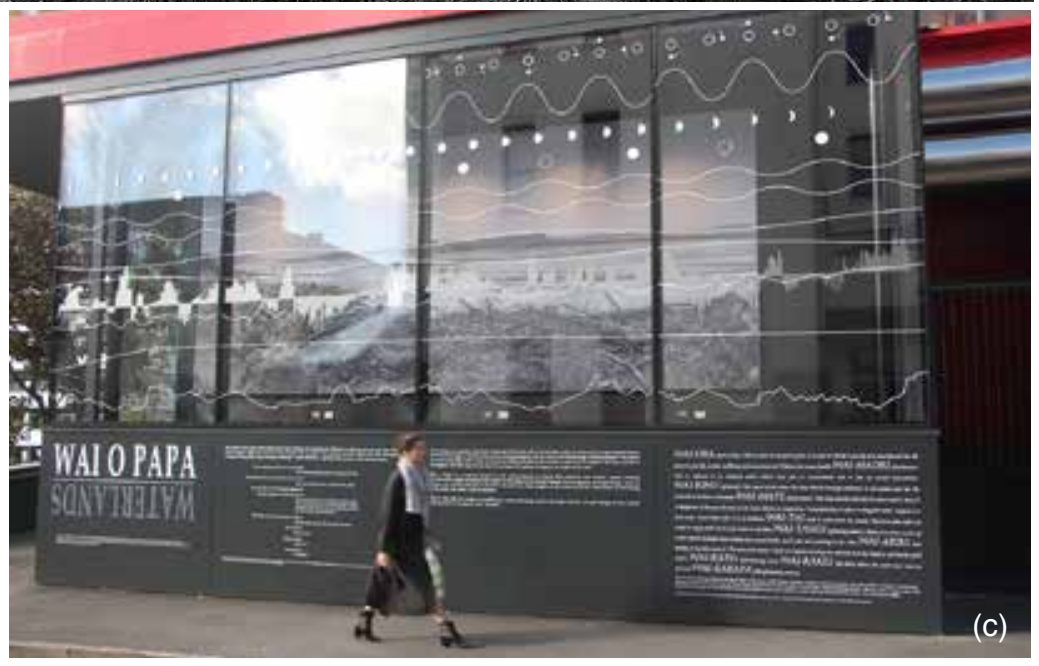




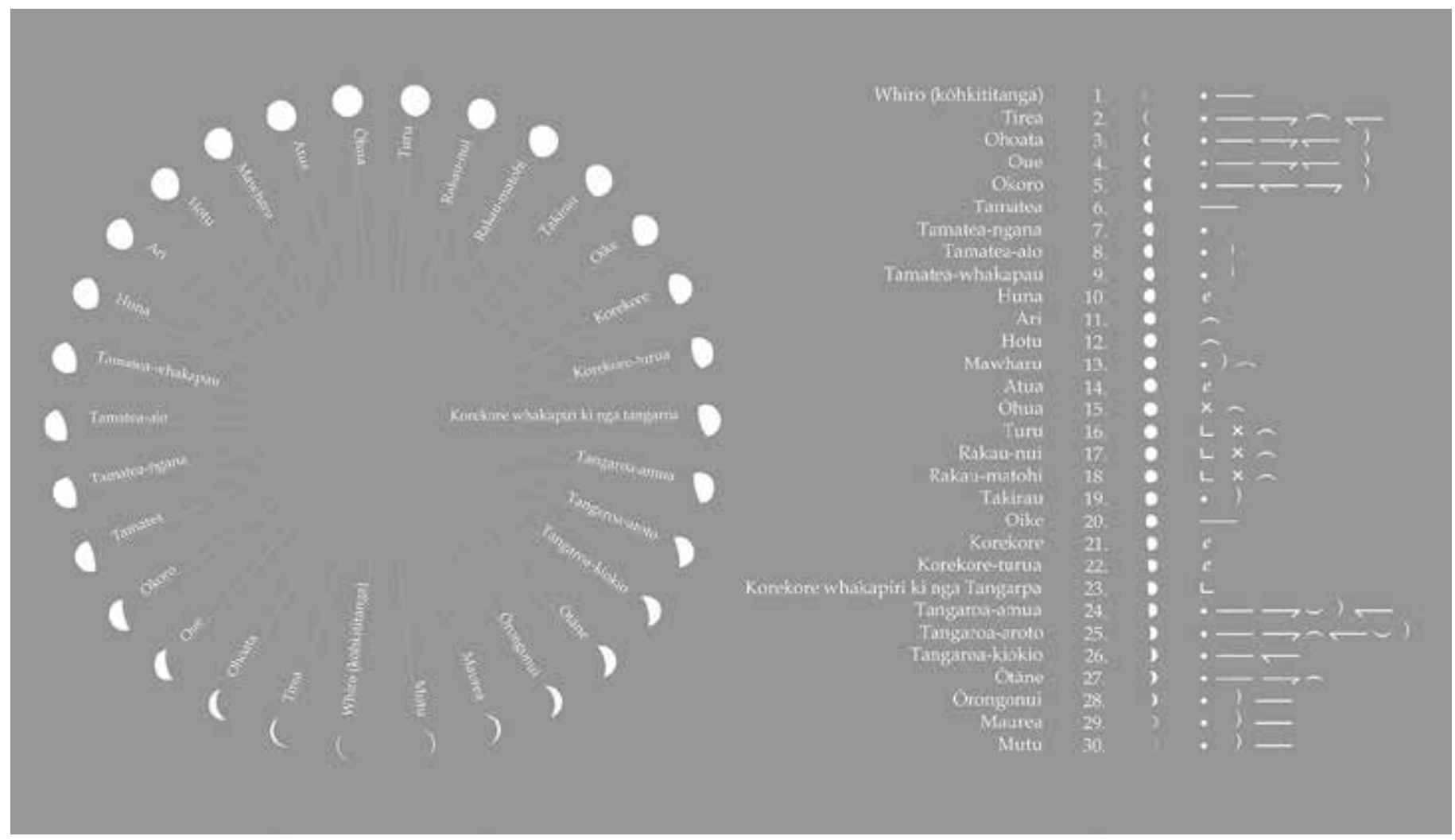

Figure 4. Maramataka prepared for second exhibition. Each entry on the right represents a lunar day, for example: "Huna" means "bad weather, food products suffer;" "Ari-roa" means "favourable for spearing eels;" "Maure" means "a fine, desirable day;" "Māwharu" means "crayfish are taken on this day;" "Ohua" means "a good day for working." For a full key, refer to: https://teara.govt.nz/en/maramataka-the-lunar-calendar/page-.

inundation can be separated into slow and fast phases. Water from the sea slowly inundates the land, but when hydrostatic pressures start to impact groundwater levels, this process accelerates and is much more difficult to manage. Importantly, these phases are separated by a threshold. During the slow phase, the length of which can be approximately calculated, there is time for management plans to be prepared to anticipate the loss of critical wetland habitat and to strategize either protection or relocation to higher ground.

With this in mind, we identified five site specific ecosystem thresholds for Tahamata farm that would not only signal a tipping point for habitats and ecologies (for example, a collapse of coastal dunes would be one indicator that might signal the shift from river mouth to estuary), but were defined as such because of their long-term impact on the farm practices and economic viability. In an important conceptual shift inspired by our mapping interpretations, we described the thresholds, much like the indicators in the maramataka, as qualitative signs in the landscape that when recognized would demand an adaptive response. This represents a shift away from typical quantitative scientific monitoring, useful but expensive and requiring specific training in analysis and interpretation, toward a qualitative approach 
based on everyday reading of landscape signs that could be immediately understood. We communicated the five thresholds, through images and stories (in the third exhibition's kōrero tuku iho shed), describing a series of narrative scenarios. ${ }^{13}$ The intent was to embed the idea of thresholds into a knowledge framework for future climate change events.

The process of mapping cycles and finding indicators allowed us to identify key productive differences between both world views. Once we identified, through science, the nature of site-specific thresholds we looked for similarities between mātauranga Māori and science knowledge systems to develop culturally appropriate ways of framing and communicating the urgency of climate change, and imagine possible adaptive responses. Art and design were critical in this process (Fig. 5).

\section{INTERVENTIONS: ADAPTATION PROJECTS}

The second, parallel research activity was based on a collective vision established by the community in wānanga (workshops) and hui (meetings):

- "Whanaungatanga ki te whenua": bring whanau (family) back to the whenua (land).

- "Puâwaitanga o te whenua": ensure the farm is economically viable.

- "Whakahokia ngā Kai o te awa": practice traditional resource management.

- "Kaitiakitanga mō āpōpo": protect the farm for future generations.

- "Tiakitanga o ngā wāhi tapu": acknowledge and protect cultural/ ancestral sites and burial areas.

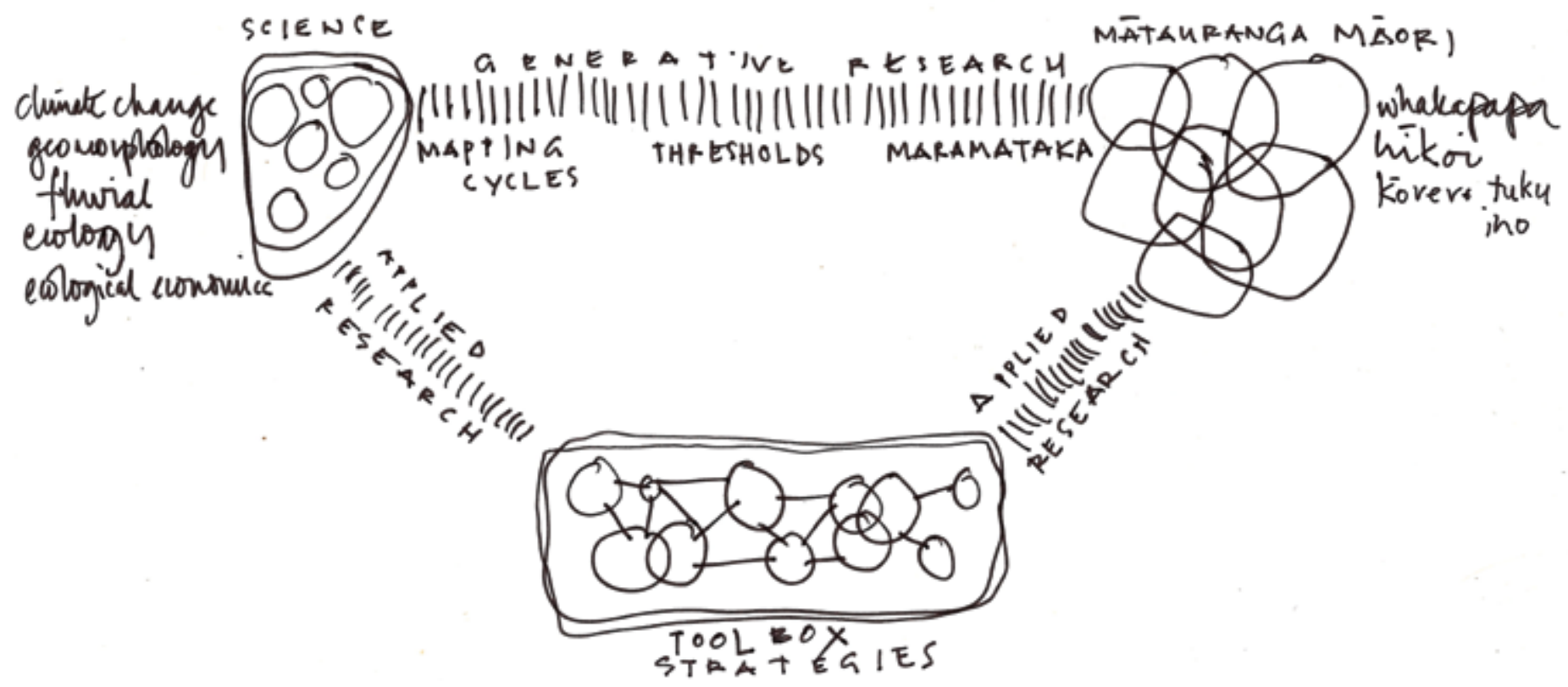

Figure 5. Diagram showing the methods employed to develop a bridge between mātauranga Māori and science. 
The research activity involved the synthesis and development through design of cultural, economic and environmental influences, a "toolbox" of nine site-specific, strategies or adaptive responses (Fig. 6). ${ }^{14}$

We saw each of these possible strategies as the response to a threshold. Because the coastal dunes had eroded and most of the wetlands - which absorb flooding and prevent salt-water intrusion - had been drained, the first design responses dealt with protecting and restoring these first lines of defense. A second set of responses related to imagining an adaptive future based on the vision, working out what was core, and then thinking about how, once constructed, that core might catalyze a series of adaptations.

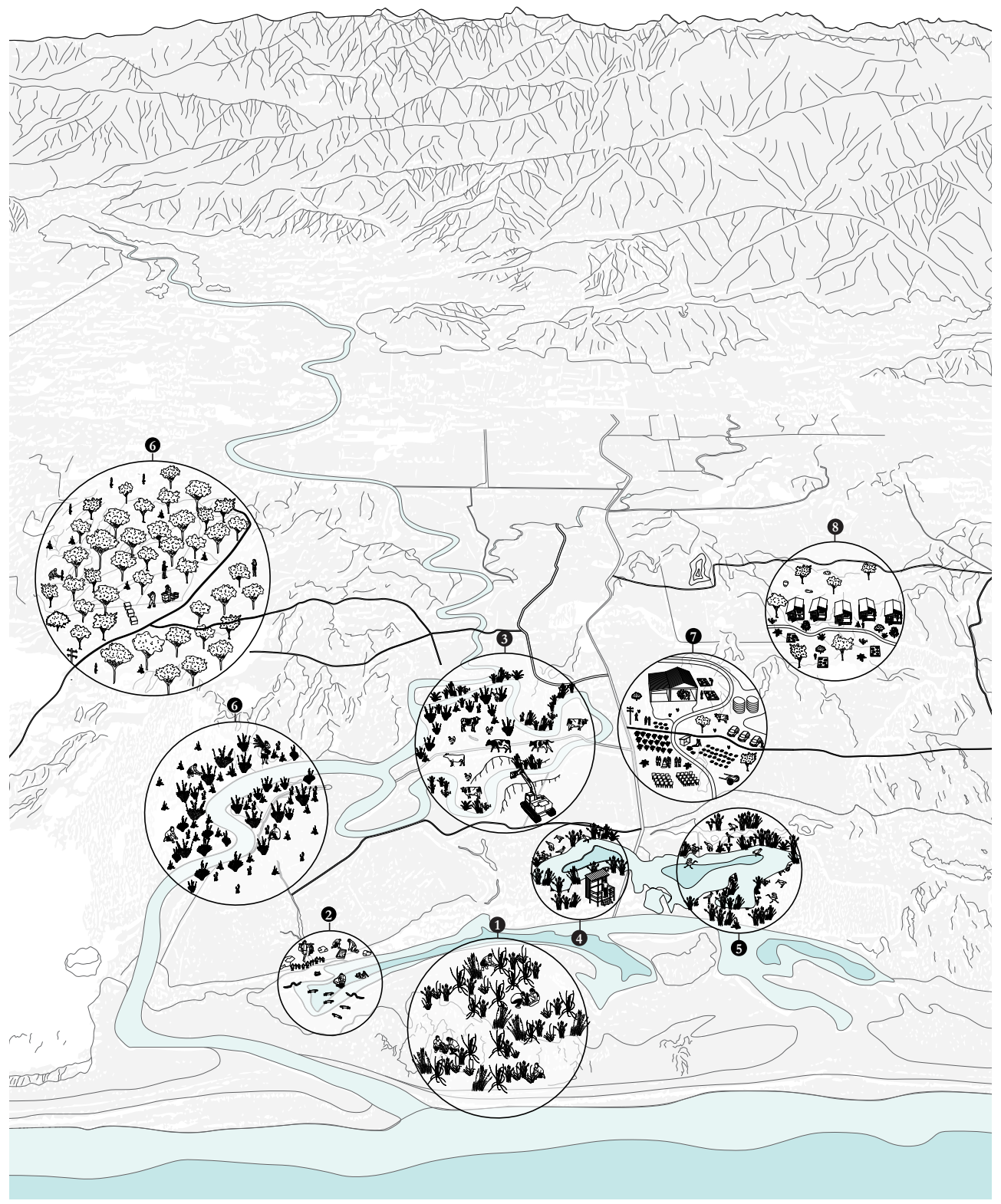

Figure 6. The toolbox strategies: 1. Protect coastal dunes; 2. Protect wetlands; 3. Protect the most arable land; 4. Protect habitat and biodiversity; 5. Make room for water; 6. Diversify farming practices; 7. Develop adaptive infrastructure; 8. Prepare and settle the high ground. 
For example, to bring "whanau back to the whenua," an infrastructural intervention might be all-weather tracks, tank water, temporary power and platforms to support cultural festivals. This intermittent use might signal and support the development of future longer-term settlement.

A third set of responses promoted diversification as a way of keeping options open. Monocultures like dairy farming close options down, destroying the potential of long-term environmental solutions in favor of the short-term fix. For example, draining wetlands will create more arable land, but in the process, it destroys the landscape's capacity to buffer climate change impacts such as flooding and salinity. These responses showed how farmers might begin to experiment with alternative agricultural practices, for example the harvesting of freshwater and marine species and the cultivation of harakeke or New Zealand flax, thereby developing a range of options to choose from should dairying ultimately fail in a wetter, coastal region.

\section{WHAKAPAPA, KŌRERO TUKU IHO, HITKOI, DESIGN, ART AND SCIENCE EXHIBITION}

The research team, together with the local community, held four exhibitions spanning 2016 and 2017. The third exhibition took place in a cluster of disused dairy sheds on the Tahamata Incorporation farm in Kuku, Horowhenua, on a site renowned for its cultural importance (Fig. 7). This exhibition did not only brought interdisciplinary work in art, culture, design and science together from an indigenous perspective, but it was also curated to express our experiments with multiple methods and forms of knowledge and our efforts to communicate Māori values in a more spatial and visceral way. For example, there were three sheds and each focused

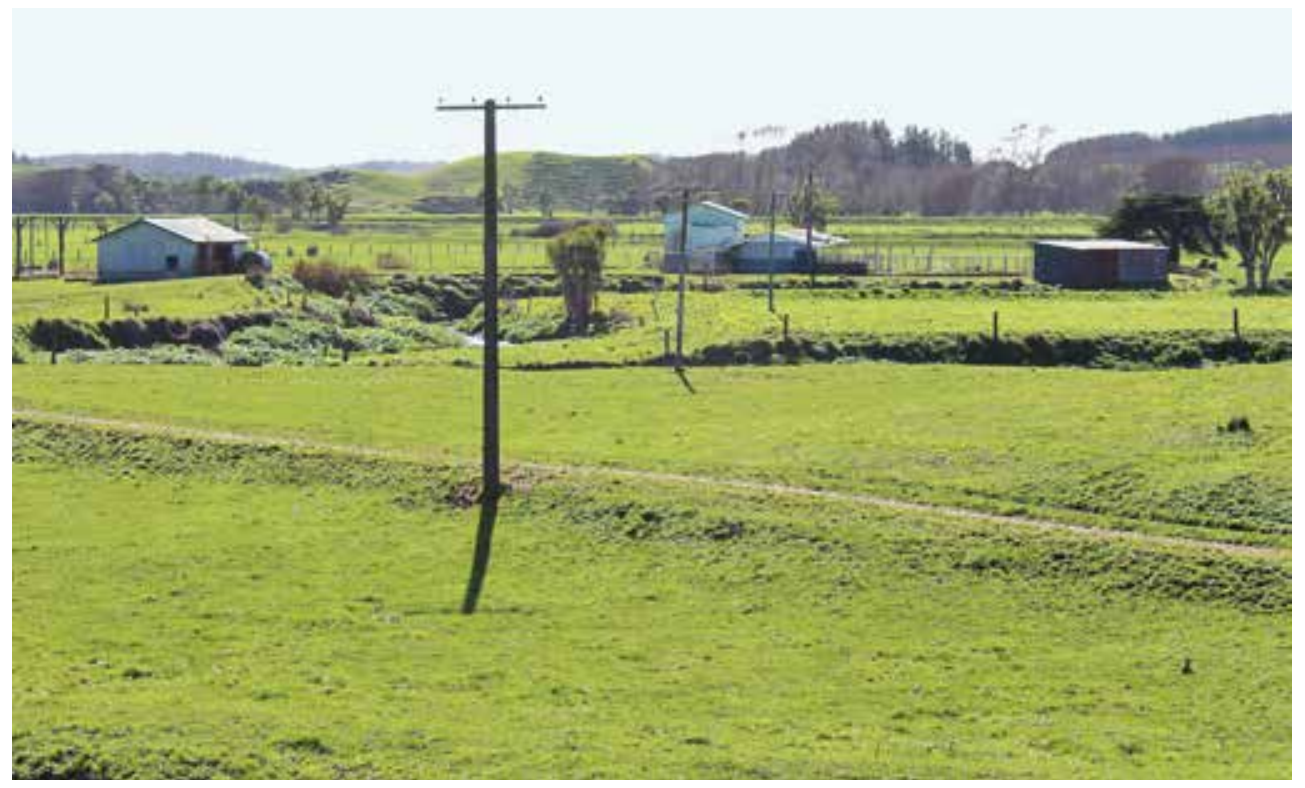

Figure 7. The dairy sheds, with the whakapapa shed on the left, the hikoi shed in the center and the kōrero tuku iho shed on the right. 
on a particular Maori creation method used in the research: whakapapa, kōrero tuku iho and hīkoi. This technique gave us an opportunity to explore our research process more deeply as well as communicating content and describing outcomes.

\section{The Whakapapa Shed}

As the oldest building in the former dairy shed complex, featuring intact original matai timber beams and structural supports, and the first building one encounters on entering the complex, it was fitting that this shed house significant cultural knowledge pertaining to the land. Five banners hung in the center of the space: on one face describing the vision and on the other the nuanced Māori words pertaining to water. Nearby was the maramataka, the graph cycles and the very large and powerful river-mouth image. The shed was kept deliberately simple, with a precise alignment of the hangings carving a space out of the atmosphere of the room to communicate a powerful sense of whakapapa: of being grounded and connected at the same time (Fig. 8).

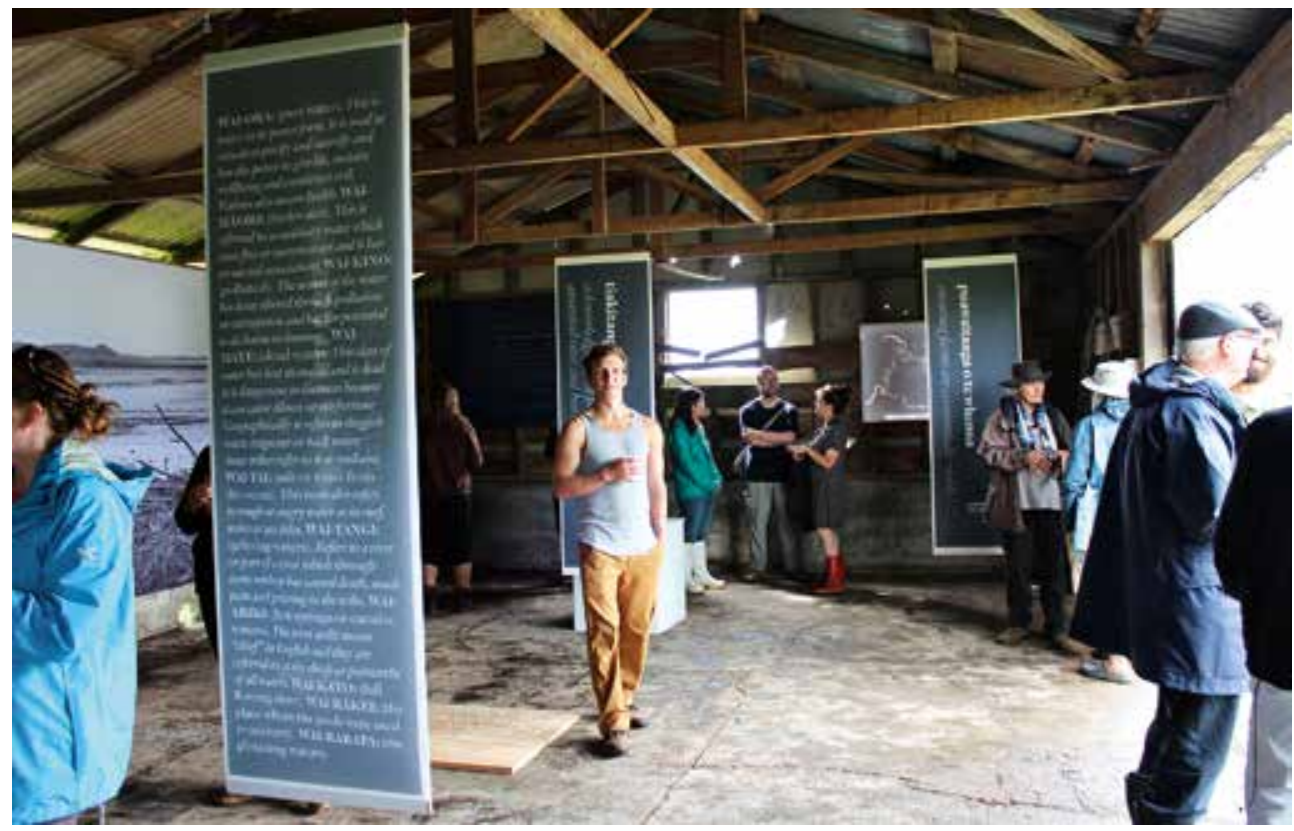

Figure 8. Whakapapa shed, showing the vision banners on the back of which are lists of the nuanced definitions of water in Te Reo Māori language, and to the left, the large photo of the Ohāu river mouth.

\section{The Kōrero Tuku Iho shed}

The kōrero tuku iho shed was our first attempt at embedding the story of thresholds on the farm as a stimulus for action. Towards the front of the building, visitors physically navigated a sequence of threshold spaces 
created by hangings, with images from the farm of the thresholds-in-action, captured in real time initially as infrequent events but ultimately resolving into permanent features in the landscape. Each image was framed by a question "What would you do if...?" Once the thresholds were crossed, in the dark recesses at the back of the building, a series of light models described the possible land based adaptive responses to those thresholds (Fig. 9).

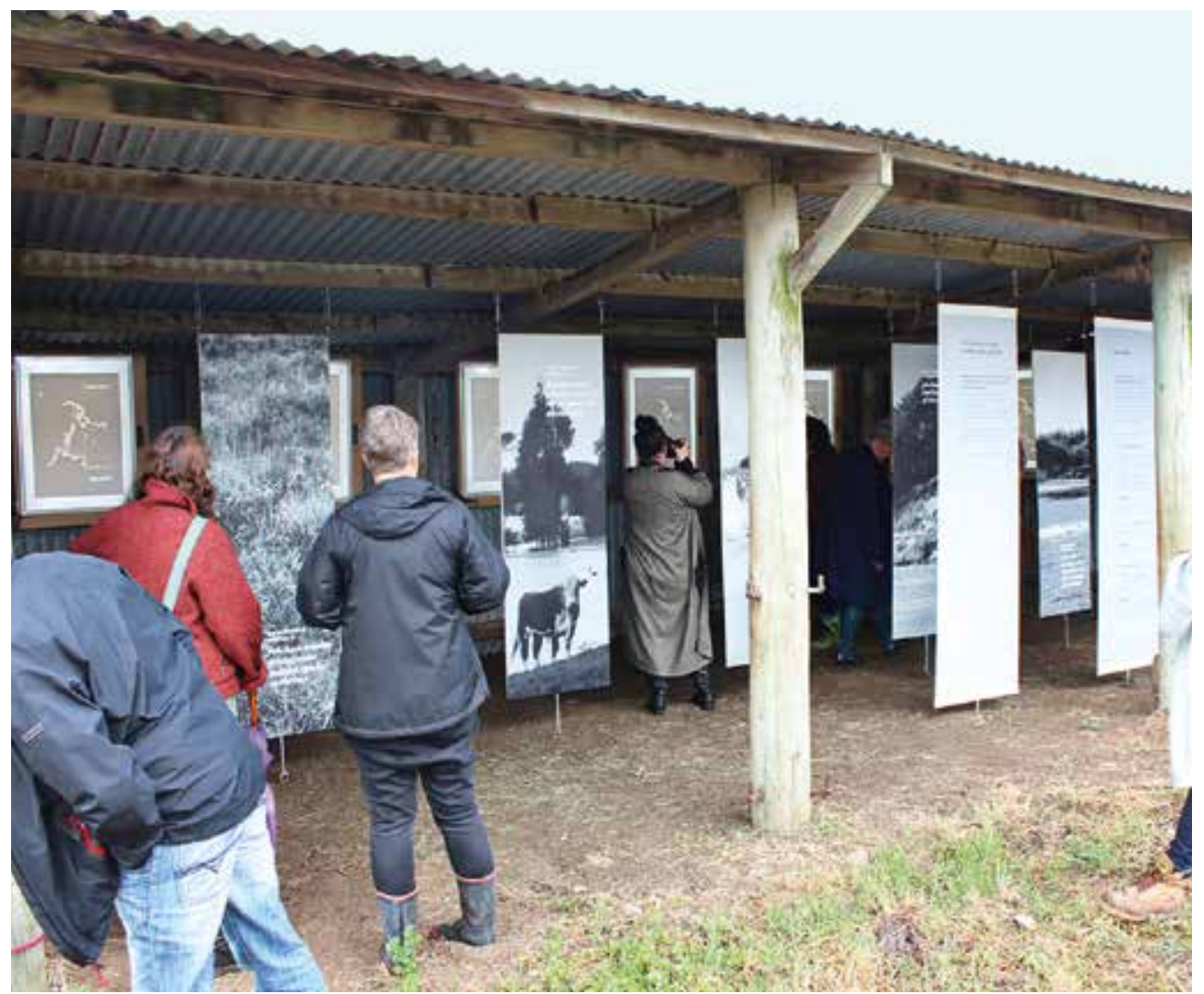

Figure 9. The kōrero tuku iho shed.

\section{The Hīkoi Shed}

A large milking shed encapsulated the key findings of hīkoi (the series of walks across lands) that gave rise to speculative design work and visual devices that offered the toolbox of solutions to farmers.

The exhibition gave us a chance to develop our ideas around the methodologies as key drivers for the work. Using the buildings as vehicles for whakapapa, körero tuku iho and hīkoi allowed us to explore the idea of each as spatial as well as conceptual, communicated through the body as well as through narrative. This gave more weight and depth to the interdisciplinary work and made the communication of climate change related ideas visceral and potent. 


\section{DOWSE EXHIBITION: "THIS TIME OF USEFUL CONSCIOUSNESS: POLITICAL ECOLOGY NOW"}

The final exhibition in this series arose from an invitation to exhibit as part of This Time of Useful Consciousness: Political Ecology Now from April 13 to July 31, 2017, at the Dowse Art Museum, Wellington, New Zealand (Fig. 10). Useful consciousness is described as "those few moments between being deprived of oxygen and passing out, a period in which the full extent of the danger is known, but it is still possible to act." 15 The exhibition showed a generation of contemporary artists' works that addressed the urgency of global environmental issues and the relationship between climate change, personal agency, and economic, political and social factors. ${ }^{16}$

In this exhibition, we edited the content of the previous exhibition, reinterpreting the physical experience of critical thresholds as a call to action at "the last moment of useful consciousness" and offering a strategic view of the future in the light box installations. The exhibition also included a series of talks, with discussion about the roles of exhibitions, the potential of mātauranga Māori, and the strengths of interdisciplinarity. The talks raised the significance of the exhibition to a political level and discussed the cultural importance of adaptive shifts in behavior and practice. For example, the exhibitions aroused awareness through the graph cycle and maramataka mappings, and immersed people in the experience of whakapapa and the narrative of the körero tuku iho, suggesting how these values as embodied experiences might be shared across cultures, to effect lasting climate change adaptations on coastal lands. In both exhibitions, scientific data was not presented alone, but framed through its interconnections with other matters: how we see cycles happening; how adaptations are linked to thresholds; how they can reinforce rather than change traditional cultures; and how they can be made relevant.

The curation of the exhibition thus showed the potential to draw on cultural perspectives and cultural knowledge to enrich the practice, culture and politics of issues relating to climate change.

The exhibition also raised discussions on the potential of more productive collaboration between disciplines. The outcomes in this project were complex, and the exhibition displayed a mix of methods, strategies and solutions, which were distinct but also interconnected. It showed the power of interdisciplinarity to develop knowledge and shift practice, while maintaining the distinctiveness and integrity of each contribution, whether that be western science, traditional knowledge, art or design practice.

The final question that arose out of the discussion at the Dowse was related to the concept of indigeneity. As one person said, "I feel connected to this way of thinking, but I am not Māori." Mātauranga Māori, in its capacity to see the world as holistic and interconnected, allows us to embrace change that respects both cultural and scientific forms of knowledge. This kind of holistic worldview has implications for everyone beyond 
coastal Horowhenua, and beyond New Zealand. The drawing of bridges, in exhibition, between culture and between worldviews and knowledge systems is a particularly powerful and important way of developing land, culture and technology based climate change solutions.

\section{DISCUSSION}

\section{Overview}

Climate change related to transformative change for indigenous coastal communities can be, at best, a modest and slow-moving process that relies on the values of community ownership and the capacity local selforganization. This kind of change happens from the ground up. It requires a closer, more intuitive reading of what is happening, the relationships between dramatic ecological shifts - occurring in human time quite slowly and described in this essay as thresholds - and possible action. It also requires the will to act, difficult to muster when impacts seem distant, but remarkably present when one's life and livelihood are under immediate threat. Although the adaptive process will need to continue across generations, coastal communities need to start thinking about climatechange adaptation strategies, plan for them, and act now.

Adapting with, rather than in spite of, the landscape acknowledges the potential of landscape's abundance and complexity as a source of future options. It facilitates the agency of landscape and encourages adaptability, making a difference to communities and settlements now, as well as

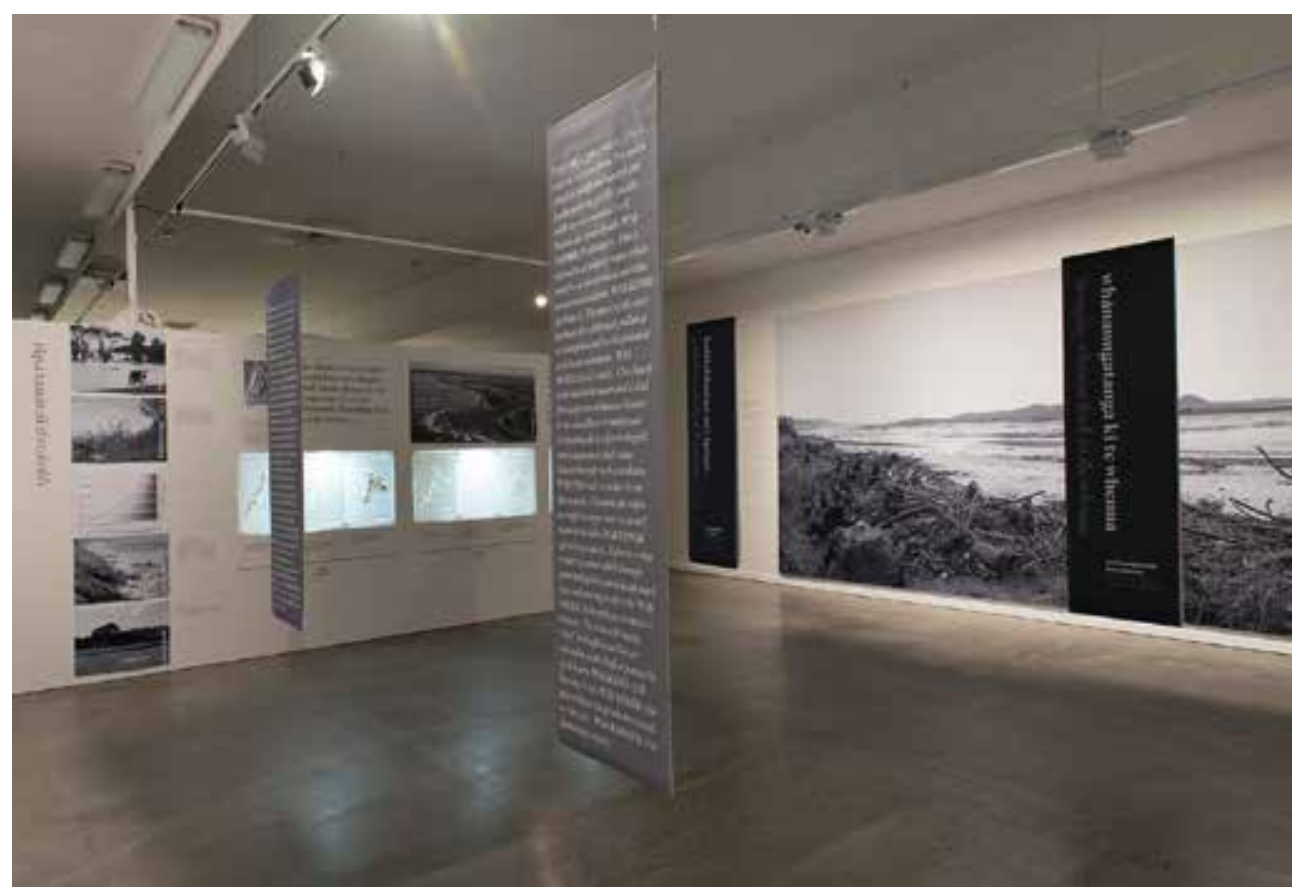

Figure 10. The Dowse exhibition with the river mouth photo on right and thresholds and light box strategy models on the wall behind. 
enhancing effective adaptive responses to climate change. Research into current farm practices and how those relate to the landscape of which the farm is a part illustrates how the response to climate change on coastal lands might be seen as part of a whole of environment and whole of community imperative.

\section{Methods: a Framework for Collaboration}

The research was framed around two key agendas: the first to explore a variety of methods that might facilitate cross-cultural and cross-disciplinary collaboration, the second to find productive ways for the community to move forward.

This project was the stimulus for a deeper exploration of the use of art and design in the bridging of indigenous and non-indigenous methods and values as the foundation for cross-cultural collaboration. The research provided a vehicle for us to extend our thinking and experiment with strategies that might accommodate two different worldviews. The interpretation, through mapping, of the shifting relationships between land water and atmosphere over time from different cultural perspectives, shed light on the subtleties of both perspectives. Essentially, in response to the research question: how might one catalyze the capacity of a place and its people to adapt to climate change? The mapping encouraged us to look at the "when," as well as the "what" and the "how."

The design - the "what and how" - was based on the long-term vision established by the community, and informed by both scientific data about geomorphology and weather patterns, and stories about the relationship between the land and its people told during hui and wānanga. It was based on a holistic vision, not complete in the nature of a master plan but rather conceived of as a series of land based strategies, an open-ended toolbox that allowed the community to decide what to do when they were ready. As a technique, the toolbox acknowledges and accommodates the importance of decisions made on the ground, over time as necessary, and is enabling and adaptive. As well as the toolbox being open ended, each individual strategy is open ended too, creating opportunities if implemented, for sustainable growth, rather than closing them down. ${ }^{17}$

But because each strategy represents an investment of time and money, and the farm board is relatively conservative and not convinced about the science or urgency of climate change, the real challenge for this research project was to give them some sense of "when" to act - when to make that critical decision. This research takes the "when" out of the hands of the unpredictability of climate change science and government policy and puts it in the hands of the community. It connects acting with noticing.

This qualitative rather than quantitative approach feels significant because another challenge of the research has been how to communicate something that seems distant, as something present, real and threatening. 
Doing this through art and design is powerful and ultimately enlightening because art and design are direct and immediate. This then may be the most important role for art and design: not only to devise and communicate spatial solutions, but also to generate new ways of communicating the personal impact and the urgency of climate change.

\section{CONCLUSION}

The research suggests a guide for much-needed innovative approaches to climate change issues. It offers a number of design strategies for considering coastal settlement in conjunction with traditional scientific methods. We do not suggest that art and design or cultural knowledge replace science. Instead, we suggest a synthesis of knowledges that complement and enlarge each other. In this project, art and design provided a framework for cross cultural and interdisciplinary research. Exhibitions make interdisciplinary knowledge accessible to communities by translating and embodying complex environmental science data enhanced by mātauranga Māori or local knowledge of place. But the power of art or design lies also in its capacity to crack open binaries (science/indigenous knowledge, process/content, etc.), generating of new ways of thinking, challenging assumptions and devising solutions.

Our conclusion therefore is that instead of science preceding art or design, each should act concurrently and collectively with specific benefits that relate to the integration of nature-based and socio-cultural influences, acknowledging risks, vulnerabilities and the adaptive capacity of a place. 


\section{GLOSSARY}

Source: Māori online dictionary. Accessed at http://www.maoridictionary.co.nz/.

Ahi kā: those who live in the region.

Hapū: kinship group, clan, tribe, subtribe - section of a large kinship group.

Hīkoi: to step, stride, march, walk.

Hui: gathering, meeting, assembly.

Iwi: extended kinship group, tribe, nation, people, nationality, race - often

refers to a large group of people descended from a common ancestor.

Kaumātua: elders.

Kaupapa: policy, matter for discussion, plan, scheme, proposal, agenda, subject.

Kaitiaki: trustee, minder, guard, custodian, guardian, keeper.

Kōrero tuku iho: oral traditions.

Marae: courtyard - the open area in front of the wharenui, where formal greetings and discussions take place. Often also used to include the complex of buildings around them.

Ngāti: prefix for a tribal group.

Papa kāinga: original home, home base, village.

Mātauranga: knowledge, wisdom.

Mana whenua: territorial rights, power from the land - power associated with possession and occupation of tribal land.

Mauri: life principle, special nature, a material symbol of a life principle, source of emotions.

Wānanga: forum, onference, workshop.

Whanau: extended family, family group, a familiar term of address to a number of people.

Whakapapa: genealogy, genealogical table, lineage, descent.

\section{Notes}

1. The team included Dr. Huhana Smith Research Leader Māori, Aroha Spinks and Moira Poutama from Te Rangitāwhia Whakatupu Mātauranga Ltd, landscape architects Professors Penny Allan and Martin Bryant, and Professor Martin Manning. The latter was Director of the IPCC Working Group I Technical Support Unit, which produced the fourth Assessment Report on Climate Change, and Dr. Jane Richardson, whose research is focused on fluvial geomorphology, and the influence of climate change on river systems and catchments in New Zealand.

2. The protocol was inspired by Mason Durie's work on the Treaty of Waitangi House. Refer especially to Mason Durie, "Exploring the Interface Between Science and Indigenous Knowledge." Paper presented at the 5th APEC Research and Development Leaders Forum Capturing Value from Science, Christchurch, New Zeal., 2004. The protocol suggests that research "at the interface" should be preceded by an apprenticeship in culture, history, cosmogony, customs and language; be characterized by a fundamental shift in method; lead to innovation, greater relevance, and additional opportunities for the creation of new knowledge; have active Māori participation as researchers and respondents; use mainstream and Māori tools for analysis; include Māori values and concepts as a basis for assessing the relevance and potential benefits of the research; have a code of ethics; and not make liberal use of mātauranga Māori in a manner which runs the risk of distorting both context and content. 
3. Part of this research process was to analyze the impact on the farm of a 1-3 m [3.3-9.8 ft.] sea level rise, using LIDAR data and a simple, two-dimensional assessment of the relationship between sea and ground levels. The drawings generated suggested that with a 3 m sea level rise up to $40 \%$ of existing arable land would be inundated.

4. Tahamata Incorporation is a shareholder, collectively owned coastal farm with a Board of Directors governed by the Incorporation clauses within the Te Ture Whenua Māori Act 1993.

5. Environmental data for the farm was compiled during previous research on which Smith's PhD was based. For more information see Manaaki Taha Moana: Enhancing Coastal Systems for Iwi: State of Ecological/Cultural Landscape Decline of the Horowhenua Coastline between Hokio and Waitohu Streams, 2014. Available online at: http://www.mtm.ac.nz.

6. Penny Allan and Huhana Smith, "He Whakawhiti Kōrero: A Conversation about a Collaboration in Art, Design and the Environment," in Colonial Gothic to Māori Renaissance: Essays in Memory of Jonathan Mane-Wheoki, ed. Conal McCarthy and Mark Stocker (Wellington, New Zeal.: Victoria University Press, 2017), 238-48.

7. Huhana Smith, Penny Allan, Martin Bryant, Derrylea Hardy, Martin Manning, Murray Patterson, Moira Poutama, Abdallah Richards, Jane Richardson, and Aroha Spinks, Adaptation Strategies to Address Climate Change Impacts on Coastal Māori Communities in Aotearoa-New Zealand: A Case Study of Dairy Farming in the Horowhenua Coastal Zone (Palmerston North, New Zeal.: Massey University, 2017).

8. Dieter Helm, Natural Capital: Valuing the Planet (New Haven CT, USA: Yale University Press, 2015).

9. Susan (Huhana) Smith, "Hei Whenua Ora and Iwi Approaches for Reinstating Valued Ecosystems within Cultural Landscape" (PhD diss., Massey University, 2007).

10. Climate Change: Synthesis Report. Contribution of Working Groups I, II and III to the Fifth Assessment Report of the Intergovernmental Panel on Climate Change, ed. R.K. Pachauri and L.A. Meyer (Core Writing Team) (Geneva, Switz., 2014).

11. Fikret Berkes, "Indigenous Ways of Knowing and the Study of Environmental Change," Journal of the Royal Society of New Zealand 39, no. 4 (2009): 153. doi: $11.1080 / 03014220909510568$.

12. Haunani H. Kane, Charles H. Fletcher, L. Neil Frazer and Matthew B. Barbee, "Critical Elevation Levels Due to Sea-level Rise in Hawai'l," Regional Environmental Change 15 (2015): 1679-87. doi: 10.1007/s10113-014-0725-6.

13. In the third exhibition, these were installed as physical thresholds through which one navigated in order to reach the adaptive solutions shown at the back of the shed. Banners of image and text ask "what would you do if?": coastal dunes erode during storms and high tides; you have trouble getting pasture species to thrive; you lose arable land to riverbank collapse; floods restrict access to the property for several days; you notice standing water in paddocks normally dry in winter.

14. The toolbox comprised nine strategies: Protect coastal dunes, Protect and establish dunes as the first line of defense; Protect wetlands Establish wetlands as a buffer against sea level rise and flooding; Protect the most arable land Establish and plant embankments to protect the most arable land; Protect habitat and biodiversity; Restore existing and regenerate new habitats with links between ecosystems e.g. salty, brackish, freshwater wetlands, dune habitats, terrestrial vegetation; Make room for water Anticipating areas for expansion of water will reduce ecological disturbance and protect arable land from inundation. Activating the loop will prevent erosion, slow the river down and improve hydrology; Diversify farming practices Minimise economic risk by maximising diversity into endemic agricultural techniques e.g. aquaculture, forestry, manuka etc; Develop adaptive infrastructure Adapt existing farm buildings for an extra revenue stream. Establish robust all weather connections: (bridges, boardwalks, roads connecting high ground) to serve as the foundational infrastructure for all future development; Celebrate the high ground; Provide infrastructure for cultural festivals that might eventually be the basis for new settlement; Settle the high ground; Establish plans for existing whare and new papakainga to be resited on flat, unproductive, north facing high ground, above the $5 \mathrm{~m}$ [16 ft.] level.

15. Melanie Oliver, Senior Curator at the Dowse Art Museum, sourced the title from Ralph Chapman's 2015 publication, Time of Useful Consciousness: Acting Urgently on Climate Change. Wellington, New Zeal.: BTW. Available at: http://bwb.co.nz/books/time-of-usefulconsciousness. 
16. Mark Amery, "Staying Conscious," The Big Idea (2017), accessed 31 July 2017. https://www.thebigidea.nz/stories/staying-conscious.

17. The wholesale draining of the regions network of wetlands in the nineteenth century is an example of closing down options: a short-term solution with disastrous long-term ramifications.

\section{Credits}

Figure 1: photo by Laurie Cairns, Palmerston North, June 6, 2009. (c) Aerial photography. Figure 2: drawings by Abdallah Richards.

Figure 3a: graphic by Penny Allan and Abdallah Richards.

Figure 3b: photo by Martin Manning.

Figures $3 c$ and 7-9: photos by Penny Allan.

Figure 4: drawing by Huhana Smith and Abdallah Richards.

Figure 5: drawing by Martin Bryant and Penny Allan.

Figure 6: drawing by Miguel Guilarte and Charlie Curtin.

Figure 10: photo by Huhana Smith.

Martin Bryant is a landscape architect, architect and urban designer with more than three decades' experience in private practice and academia. His multi-award winning design projects are recognised for environmental benefits, cultural sensitivity, and urban design. And his globally significant research led to his authorship of urban ecology and resilience policy paper for United Nations Habitat III conference in Quito, Ecuador, 2016. He is now Head of the Architecture School at the University of Technology Sydney, and continues to research in designing for resilience. E-mail: Martin.Bryant@uts.edu.au

Penny Allan is a Professor of Landscape Architecture at the University of Technology in Sydney. She is co-founder of the design research practice OUTPOST. Her three most recent design research projects MOVED to Design, Earthquake Cities of the Pacific Rim, and Rae ki te Rae deal with the relationship between environment, culture, resilience and design and have all received national awards. Her latest research looks at cultural resilience and climate change migration in the Pacific. E-mail: penny.allan@uts.edu.au

Huhana Smith (Ngāti Tukorehe, Ngāti Raukawa ki Te Tonga) is an artist and academic with wide-ranging experience in Māori visual art and museum practice, exhibition planning and implementation, indigenous knowledge and science research. She is currently Head of Whiti o Rehua School of Art, Toi Rauwhārangi, College of Creative Arts, at Massey University, Wellington, New Zealand. She is co-leading another active participatory, multi-disciplinary, collaborative and kaupapa Māori research project called "Risk Management Planning for Climate Change Impacts on Māori Coastal Ecosystems and Economies," 2017-2019.

E-mail: Huhana.Smith@massey.ac.nz 